\title{
Characteristics and Formation Mechanisms of Sulfate and Nitrate in Size-segregated Atmospheric Particles from Urban Guangzhou, China
}

\author{
Feng Jiang ${ }^{1,2}$, Fengxian Liu ${ }^{1,2}$, Qinhao Lin ${ }^{1}$, Yuzhen Fu ${ }^{1,2}$, Yuxiang Yang ${ }^{1,2}$, Long Peng ${ }^{1,2}$, \\ Xiufeng Lian ${ }^{1,2}$, Guohua Zhang ${ }^{1 *}$, Xinhui $\mathrm{Bi}^{1}{ }^{1}$, Xinming Wang ${ }^{1}$, Guoying Sheng ${ }^{1}$ \\ ${ }^{I}$ State Key Laboratory of Organic Geochemistry and Guangdong Key Laboratory of Environmental Resources Utilization \\ and Protection, Guangzhou Institute of Geochemistry, Chinese Academy of Sciences, Guangzhou 510640, China \\ ${ }^{2}$ University of Chinese Academy of Sciences, Beijing 100049, China
}

\begin{abstract}
Various water-soluble inorganic compounds, including $\mathrm{Na}^{+}, \mathrm{NH}_{4}{ }^{+}, \mathrm{K}^{+}, \mathrm{Ca}^{2+}, \mathrm{Mg}^{2+}, \mathrm{Cl}^{-}, \mathrm{NO}_{3}{ }^{-}, \mathrm{PO}_{4}{ }^{3-}$ and $\mathrm{SO}_{4}{ }^{2-}$, were analyzed in 130 sets of size-segregated $(<0.49,0.49-0.95,0.95-1.5,1.5-3.0,3.0-7.2$ and $7.2-10.0 \mu \mathrm{m})$ aerosol samples collected from March 2013 to April 2014 in Guangzhou, China. $\mathrm{SO}_{4}{ }^{2-}$ was unimodally distributed and peaked during a typical droplet mode $(0.49-0.95 \mu \mathrm{m})$. However, the distribution of $\mathrm{NO}_{3}{ }^{-}$significantly varied across the four seasons. It was unimodally distributed in summer and autumn, peaking in the coarse mode (3.0-7.2 $\mu \mathrm{m})$, and bimodally distributed in winter and spring, peaking in the size ranges of $0.49-0.95 \mu \mathrm{m}$ and 3.0-7.2 $\mu \mathrm{m}$, respectively. The coarse-mode $\mathrm{NO}_{3}{ }^{-}$was mainly related to the influence of soil/dust. The additional mode during winter and spring was attributable to the formation of ammonium nitrate. Compared to clean days, polluted days favored the formation of $\mathrm{SO}_{4}{ }^{2-}$ in summer and autumn and $\mathrm{NO}_{3}{ }^{-}$in winter and spring. The sulfur oxidation ratios (SORs) for $<0.49,0.49-0.95$ and $0.95-1.5 \mu \mathrm{m}$ particles were negatively correlated with the relative humidity (RH) in spring, summer and autumn, respectively. However, the SORs for 0.49-3.0 $\mu \mathrm{m}$ particles were positively correlated with the $\mathrm{RH}$ in winter, implying an important contribution from the aqueous oxidation of $\mathrm{SO}_{2}$. Further analysis shows that the $\mathrm{SO}_{4}{ }^{2-}$ in $<0.49 \mu \mathrm{m}$ particles was formed primarily through gasphase photochemical oxidation of $\mathrm{SO}_{2}$ during all four seasons. The formation of $\mathrm{NO}_{3}^{-}$was mainly attributable to heterogeneous reactions for 1.5-3.0 $\mu \mathrm{m}$ particles year-round and homogeneous gas-phase reactions for $<0.49 \mu \mathrm{m}$ particles in winter. Correlation analysis also indicates a positive influence from biomass burning on the formation of nitrate and sulfate. The average $\mathrm{pH}$ of $\mathrm{PM}_{3}$ was calculated to be 2.6-5.6. Thus, the aqueous oxidation of $\mathrm{SO}_{2}$ by $\mathrm{NO}_{2}$ plays a limited role in the formation of sulfate in the atmosphere of Guangzhou.
\end{abstract}

Keywords: Water-soluble inorganic compounds; Sulfate; Nitrate; Sulfur oxidation ratio; Nitrogen oxidation ratio; Guangzhou.

\section{INTRODUCTION}

Atmospheric particulate matter has a significant impact on human health, air quality and climate (Poschl, 2005; Seinfeld and Pandis, 2006). Water-soluble inorganic compounds are the main constituents of particulate matter in the air and account for $\sim 30-50 \%$ of $\mathrm{PM}_{2.5}$ (Lai et al., 2007; Cao et al., 2012; Wu et al., 2017). $\mathrm{SO}_{4}{ }^{2-}$ and $\mathrm{NO}_{3}{ }^{-}$, largely present in the forms of $\left(\mathrm{NH}_{4}\right)_{2} \mathrm{SO}_{4}$ and $\mathrm{NH}_{4} \mathrm{NO}_{3}$ (Wang et al., 2016b), respectively, account for more than $40 \%$ of the total water-soluble inorganic ions (TWSI) (Yao et al., 2002; Yue et al., 2010; Chang et al., 2013; Yue et al., 2015). They are identified as the major drivers for the

\footnotetext{
* Corresponding author.

E-mail address: zhanggh@gig.ac.cn
}

formation of haze. Consequently, reductions in $\mathrm{SO}_{4}{ }^{2-}$ and $\mathrm{NO}_{3}^{-}$aerosols are of significance for $\mathrm{PM}_{2.5}$ pollution control and air quality improvement.

Formation mechanisms of $\mathrm{SO}_{4}{ }^{2-}$ and $\mathrm{NO}_{3}{ }^{-}$in the complex atmosphere are still under debate. Sulfate can be formed through the oxidation of $\mathrm{SO}_{2}$ by gas-phase reactions with $\mathrm{OH} \cdot$ (Stockwell and Calvert, 1983; Blitz et al., 2003) and by aqueous oxidation of $\mathrm{SO}_{2}$ with dissolved $\mathrm{H}_{2} \mathrm{O}_{2}$ or with $\mathrm{O}_{2}$ under the catalysis of transition metal (Seinfeld and Pandis, 2006). Aqueous oxidation is regarded as the most important pathway for the formation of $\mathrm{SO}_{4}{ }^{2-}$ (Tan et al., 2009b; Huang et al., 2016). A recent study found that the aqueous oxidation of $\mathrm{SO}_{2}$ by $\mathrm{NO}_{2}$ was the key process involved in the efficient formation of sulfate on wet aerosols or cloud droplets with $\mathrm{NH}_{3}$ neutralization (Cheng et al., 2016; Wang et al., 2016). However, Guo et al. (2017) and Liu et al. (2017b) suggested that the above aqueous oxidation pathway for sulfate production may not be 
relevant in China due to the acidic nature of aerosol, with a $\mathrm{pH}$ range of 3.0 to 4.9 . $\mathrm{NO}_{3}^{-}$formation is dominated by the gas-phase reactions of $\mathrm{NO}_{2}$ with $\mathrm{OH} \cdot$ during daylight followed by condensation, and the heterogeneous reactions of nitrate radical $\left(\mathrm{NO}_{3}\right)$ or $\mathrm{N}_{2} \mathrm{O}_{5}$ during nighttime (Pun and Seigneur, 2001; Seinfeld and Pandis, 2006).

Particle size could be a very useful indicator to understand the formation mechanisms of $\mathrm{SO}_{4}{ }^{2-}$ and $\mathrm{NO}_{3}{ }^{-}$ (Liu et al., 2008). Condensation-mode $\mathrm{SO}_{4}{ }^{2-}$ is mainly formed by gas-to-particle conversion, while droplet-mode $\mathrm{SO}_{4}{ }^{2-}$ is mainly attributed to cloud processing (Meng and Seinfeld, 1994). Fine-mode $\mathrm{NO}_{3}{ }^{-}$is formed by nitric acid with ammonia, and coarse-mode $\mathrm{NO}_{3}{ }^{-}$is mainly formed by heterogeneous reactions of nitric acid or $\mathrm{NO}_{2}$ with coarse particles, such as sea-salt, dust or soil particles (Seinfeld and Pandis, 2006). Such distinct processes could lead to different size-segregated characteristics of $\mathrm{SO}_{4}{ }^{2-}$ and $\mathrm{NO}_{3}{ }^{-}$ (Wang et al., 2017). In addition, their dominant pathways may vary with regions and seasons, depending on various factors, including temperature, atmospheric oxidation capacity, levels of gaseous precursors, aerosol size, water content and acidity. High temperature facilitates the oxidation of $\mathrm{SO}_{2}$ to $\mathrm{SO}_{4}{ }^{2-}$ and the dissociation of $\mathrm{NH}_{4} \mathrm{NO}_{3}$ in particulate matter (Tai et al., 2010). Aerosol pH is also an important parameter for the acidity-dependent heterogeneous chemical processes on aerosol surfaces, such as the oxidation of $\mathrm{SO}_{2}$ and the hydrolysis of $\mathrm{N}_{2} \mathrm{O}_{5}$ (Fu et al., 2015; Cheng et al., 2016). In addition, aerosol water content is a ubiquitous contributor to the aerosol fraction and significantly influences the chemistry involving both organic and inorganic species (Herrmann et al., 2015; Nguyen et al., 2016).

Various field measurements highlight the increased and more efficient production of $\mathrm{SO}_{4}{ }^{2-}$ and $\mathrm{NO}_{3}{ }^{-}$during severe haze events in mega-cities (i.e., Beijing, Shanghai and Guangzhou) over China (Sun et al., 2013; Huang et al., 2014; Liu et al., 2017a). The ratios of $\mathrm{SO}_{4}{ }^{2-}$ and $\mathrm{NO}_{3}{ }^{-}$to TWSI increased most dramatically in summer and autumn during polluted periods in Beijing, respectively (Huang et al., 2016). Guangzhou, a mega-city in the Pearl River Delta (PRD) region, has long suffered from air pollution (Han et al., 2014; Fu et al., 2015; Yue et al., 2015). While the level of pollution has been reduced in recent years, high production and contribution of secondary aerosol components to fine particles are still observed (Liu et al., 2017a; Li et al., 2018). $\mathrm{SO}_{4}{ }^{2-}$ was mainly formed by aqueous-phase reactions (Zheng et al., 2015) and $\mathrm{NO}_{3}^{-}$in $\mathrm{PM}_{2.5}$ was mainly formed by homogeneous reactions under ammonium-rich conditions $\left(\left[\mathrm{NH}_{4}^{+}\right] /\left[\mathrm{SO}_{4}{ }^{2-}\right]>1.5\right)$ in Guangzhou (Pathak et al., 2009; Huang et al., 2011). The increased contribution of the $\mathrm{SO}_{4}{ }^{2-}$ to $\mathrm{PM}_{10}$ from clean to hazy days was higher than the corresponding value for $\mathrm{NO}_{3}^{-}$in Guangzhou during summer (Han et al., 2014). The degrees of oxidation of $\mathrm{SO}_{2}$ and $\mathrm{NO}_{2}$ to $\mathrm{SO}_{4}{ }^{2-}$ and $\mathrm{NO}_{3}^{-}$, represented as sulfur oxidation ratio (SOR) and nitrogen oxidation ratio (NOR), respectively, were generally higher on hazy days than clean days (Tan et al., 2009a). SOR was found to be positively correlated with relative humidity $(\mathrm{RH})$ and $\mathrm{O}_{3}$ during haze episodes in Beijing and Guangzhou (Tao et al., 2012; Yang et al., 2015; Wang et al., 2016). NOR was significantly correlated with particle surface area, RH and temperature (Liu et al., 2015; Huang et al., 2016; Ge et al., 2017). However, the formation mechanisms of $\mathrm{SO}_{4}{ }^{2-}$ and $\mathrm{NO}_{3}{ }^{-}$in size-segregated particles in the PRD region are still not well understood. In addition, previous studies were mainly based on short-term observations, which did not consider the seasonal information. In the present study, water-soluble inorganic ions from size-segregated aerosol particles in Guangzhou were analyzed over different seasons. The main objective of this study was to investigate the effects of $\mathrm{O}_{3}, \mathrm{RH}$, temperature and aerosol acidity on the sizeresolved formation of $\mathrm{SO}_{4}{ }^{2-}$ and $\mathrm{NO}_{3}{ }^{-}$.

\section{EXPERIMENT AND METHODS}

\section{Collection of Size-segregated Particles}

The sampler was set up on the rooftop of a 15-m-high building at the Guangzhou Institute of Geochemistry, Chinese Academy of Sciences. The site is surrounded by heavily trafficked roads and dense residential areas, representing a typical urban location. Seasonal size-segregated PM filter samples were collected using a cascade impactor (Model SA235; Andersen Instruments, Inc.) with cut-off points at $<0.49,0.49-0.95,0.95-1.5,1.5-3.0,3.0-7.2$ and $7.2-$ $10.0 \mu \mathrm{m}$ at a flow rate of $1.13 \mathrm{~m}^{3} \mathrm{~min}^{-1}$. Before sampling, filters were preheated at $600^{\circ} \mathrm{C}$ for $4 \mathrm{~h}$. The filters were also conditioned (at $25^{\circ} \mathrm{C}$ and $50 \% \mathrm{RH}$ ) before and after sampling in an electronic hygrothermostat for $24 \mathrm{~h}$.

The details of the samples are listed in Table S1. Seasonal samples consisted of 34 sets of samples in summer (16 June-14 July 2013), 36 sets of samples in autumn (15 September-16 October 2013), 37 sets of samples in winter (13-17 December 2013 and 20 December 2013-20 January 2014), and 23 sets of samples in spring (15-29 March and 10-15 April 2014). The sample collection lasted for $12 \mathrm{~h}$, $24 \mathrm{~h}$ or $48 \mathrm{~h}$.

\section{Ions Analysis}

A part of the filter was extracted twice with a total of $10 \mathrm{~mL}$ ultrapure water $(>18.2 \mathrm{M} \Omega$ ), using an ultrasonic bath for $20 \mathrm{~min}$ at room temperature. The extracts were filtered using a $0.45 \mu \mathrm{m}$ Teflon filter. Then the solution was transferred to $25 \mathrm{~mL}$ plastic bottles, and stored in a refrigerator before analysis. The ionic components were analyzed by ion chromatograph (883 Basic IC plus; Metrohm). The limits of detection were $0.014,0.014$, $0.046,0.017,0.041,0.022,0.032,0.136$ and $0.018 \mu \mathrm{g} \mathrm{m}^{-3}$ for $\mathrm{Na}^{+}, \mathrm{NH}_{4}^{+}, \mathrm{K}^{+}, \mathrm{Ca}^{2+}, \mathrm{Mg}^{2+}, \mathrm{Cl}^{-}, \mathrm{NO}_{3}{ }^{-}, \mathrm{PO}_{4}{ }^{3-}$ and $\mathrm{SO}_{4}{ }^{2-}$, respectively. Field and laboratory blanks were analyzed in the same way as the field samples. Ion balance was used as a quality control check in the cation/anion analysis. A good linear correlation $\left(\mathrm{R}^{2}=0.94\right)$ was observed between cations and anions, with a slope of 0.79 (Fig. S1 in the supporting materials), which indicates that the ion analysis method is reliable.

\section{Gaseous Pollutants and Meteorological Data}

Hourly meteorological data (temperature, $\mathrm{RH}$ and wind speed) and gaseous pollutants data $\left(\mathrm{SO}_{2}, \mathrm{NO}_{2}\right.$ and $\left.\mathrm{O}_{3}\right)$ 
were provided by the Guangdong Environmental Monitoring Center (http://www.gdemc.gov.cn/main.html). The precipitation data were available from http://www.met eomanz.com.

\section{RESULTS AND DISCUSSION}

Since a cut-off size of $2.5 \mu \mathrm{m}$ is not available in the Anderson sampler, $3 \mu \mathrm{m}$ was defined as the boundary between fine and coarse particles in this paper. Thus, $\mathrm{PM}_{3}$ and $\mathrm{PM}_{3-10}$ represent the fine and coarse particle fractions, respectively. The TWSI components were mainly concentrated in fine particles, averaging $84.4 \%$ in $\mathrm{PM}_{3}$ and $15.2 \%$ in $\mathrm{PM}_{3-10}$ in this study, in accordance with other studies (Liu et al., 2008; Li et al., 2013; Huang et al., 2016).

The national second level for fine particles $\left(75 \mu \mathrm{g} \mathrm{m}^{-3}\right)$ was applied to separate the "polluted" and "clean" days in this study. Table 1 summarizes the concentrations of $\mathrm{SO}_{4}{ }^{2-}$ and $\mathrm{NO}_{3}^{-}$, gaseous precursors, and meteorological conditions on polluted and clean days. During the entire sampling period, several pollution episodes were observed. The levels of $\mathrm{SO}_{2}$ and $\mathrm{NO}_{2}$ on polluted days $\left(31.2 \pm 13.9 \mu \mathrm{g} \mathrm{m}^{-3}\right.$ and $84.5 \pm 34.6 \mu \mathrm{g} \mathrm{m}^{-3}$ ) were considerably higher than those on clean days $\left(15.6 \pm 6.2 \mu \mathrm{g} \mathrm{m}^{-3}\right.$ and $\left.46.4 \pm 14.5 \mu \mathrm{g} \mathrm{m}^{-3}\right)$. Similarly, higher $\mathrm{O}_{3}$ was observed on polluted days, except during spring. Higher RH on clean days, rather than hazy days, was also observed in summer, autumn and winter, most likely due to more precipitation. The seasonal pattern of pollution was similar to previous studies (Yue et al., 2015) and was mainly attributed to the influence of both the local meteorological conditions and air masses. Generally, Guangzhou mainly experienced polluted days from autumn to early spring (Yu et al., 2017), under the influence of northern air masses (Tan et al., 2009a).

\section{Characteristics and Size Distributions of Sulfate and Nitrate}

$\mathrm{SO}_{4}{ }^{2-}$ and $\mathrm{NO}_{3}{ }^{-}$were the most abundant TWSI components over the four seasons, as shown in Fig. 1. The mass contributions of $\mathrm{SO}_{4}{ }^{2-}$ and $\mathrm{NO}_{3}{ }^{-}$to TWSI were $67.8 \%, 60.1 \%, 63.7 \%$ and $66.9 \%$ on clean days and $65.4 \%$, $64.4 \%, 70.3 \%$ and $70.9 \%$ on polluted days in the spring, summer, autumn and winter, respectively. Similarly, Tan et al. (2009a) found that $\mathrm{SO}_{4}{ }^{2-}$ and $\mathrm{NO}_{3}{ }^{-}$constituted $68.4 \%$ of TWSI on summer-haze days and $67.1 \%$ on winter-haze days in Guangzhou. Increased levels of $\mathrm{SO}_{4}{ }^{2-}$ and $\mathrm{NO}_{3}{ }^{-}$ were observed on polluted days in the summer, autumn and winter. This is likely due to the relatively higher production of $\mathrm{SO}_{4}{ }^{2-}$, as evidenced by higher $\mathrm{SOR}, \mathrm{O}_{3}$ and $\mathrm{SO}_{2}$ on polluted days (Tables 1 and 2). On the contrary, an increased contribution of $\mathrm{NO}_{3}^{-}$to the TWSI was observed on polluted days in winter and spring. This is consistent with higher NOR on polluted days than clean days (Table 2). This indicates that winter and spring periods facilitate the formation of $\mathrm{NO}_{3}{ }^{-}$, particularly, on polluted days. Values of the SOR and NOR were calculated by the following equations using the corresponding molar concentrations $(n-)$.

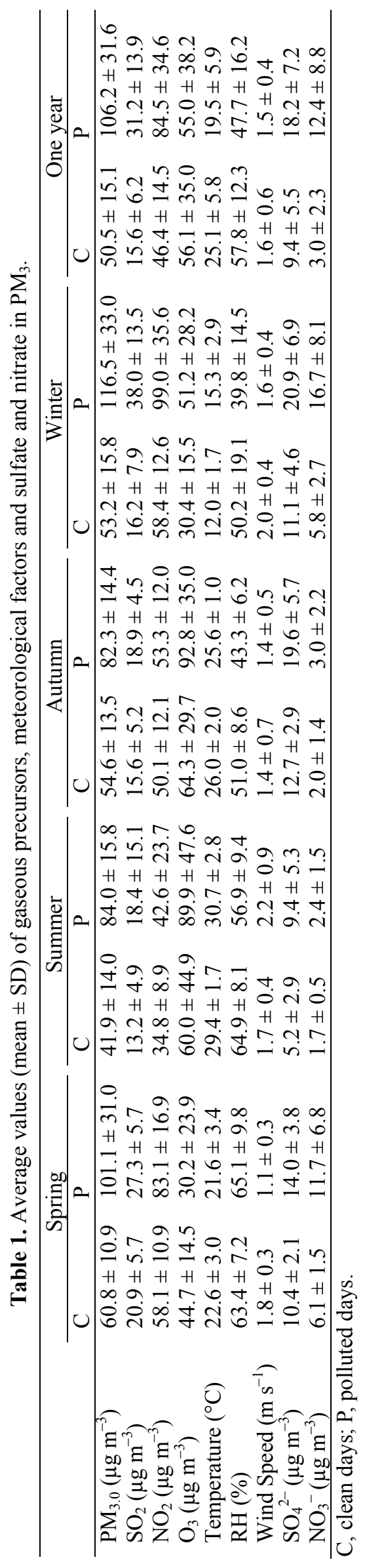


(a)

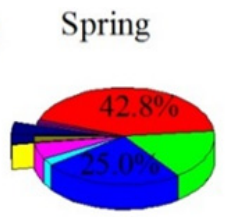

TWSI $=24.4 \mu \mathrm{g} \mathrm{m}^{3}$

(b)

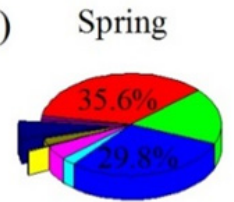

TWSI $=39.4 \mu \mathrm{g} \mathrm{m}^{3}$

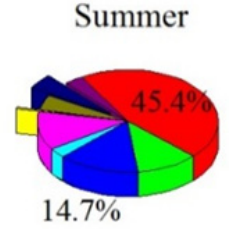

TWSI $=11.4 \mu \mathrm{g} \mathrm{m}^{3}$



TWSI $=18.2 \mu \mathrm{g} \mathrm{m}^{3}$

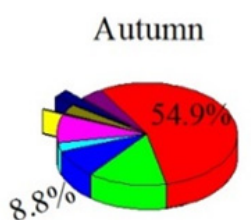

TWSI $=23.2 \mu \mathrm{g} \mathrm{m}^{3}$



TWSI $=32.3 \mu \mathrm{g} \mathrm{m}^{3}$

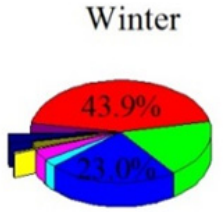

TWSI $=25.3 \mu \mathrm{g} \mathrm{m}^{3}$



TWSI $=53.0 \mu \mathrm{g} \mathrm{m}^{3}$

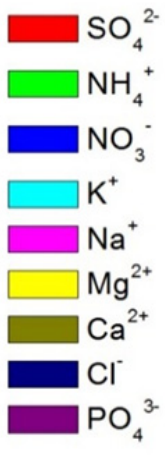

Fig. 1. The ratio of water-soluble inorganic ions to TWSI over the four seasons during (a) clean and (b) polluted days, respectively.

Table 2. Summary of SOR and NOR (mean \pm SD) on clean and hazy days over the four seasons.

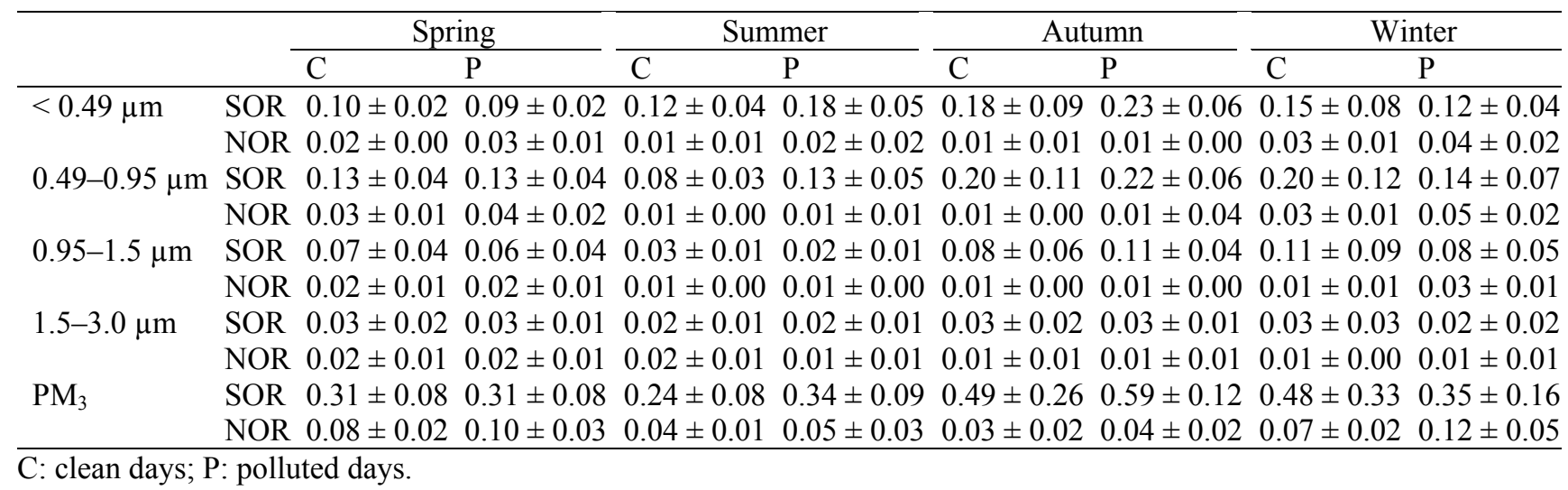

$$
\begin{aligned}
& \mathrm{SOR}=\mathrm{n}-\mathrm{SO}_{4}{ }^{2-} /\left(\mathrm{n}-\mathrm{SO}_{4}{ }^{2-}+\mathrm{n}-\mathrm{SO}_{2}\right) \\
& \mathrm{NOR}=\mathrm{n}-\mathrm{NO}_{3}{ }^{-} /\left(\mathrm{n}-\mathrm{NO}_{3}{ }^{-}+\mathrm{n}-\mathrm{NO}_{2}\right)
\end{aligned}
$$

Higher SOR and NOR indicate that more gaseous $\mathrm{SO}_{2}$ and $\mathrm{NO}_{2}$ in the atmosphere are oxidized to $\mathrm{SO}_{4}{ }^{2-}$ and $\mathrm{NO}_{3}{ }^{-}$, respectively. The Pearson correlation analysis also shows that $\mathrm{SO}_{2}$ had a positive correlation with $\mathrm{SO}_{4}{ }^{2-}(\mathrm{R}>0.56, p$ $<0.01)$ and $\mathrm{NO}_{2}$ had a positive correlation with $\mathrm{NO}_{3}{ }^{-}(\mathrm{R}>$ $0.64, p<0.01)$ in each size range. It indicates that the formation of $\mathrm{SO}_{4}{ }^{2-}$ and $\mathrm{NO}_{3}{ }^{-}$was influenced by $\mathrm{SO}_{2}$ and $\mathrm{NO}_{2}$ from local emissions. Size-segregated $\mathrm{NO}_{3}{ }^{-}$and $\mathrm{SO}_{4}{ }^{2-}$ also showed high correlations with $\mathrm{K}^{+}$, with the correlation coefficients ranging from 0.48 to $0.87(p<0.01)$ and 0.36 to $0.86(p<0.01)$, respectively.

Fig. 2 displays the size distributions of $\mathrm{SO}_{4}{ }^{2-}$ and $\mathrm{NO}_{3}{ }^{-}$ over the four seasons. $\mathrm{SO}_{4}{ }^{2-}$ was unimodally distributed and peaked at $0.49-0.95 \mu \mathrm{m}$. This is a typical droplet mode for $\mathrm{SO}_{4}{ }^{2-}$, which was mainly formed by aqueous/cloud processing (Seinfeld and Pandis, 2006). Similarly, the value of SOR was higher at $0.49-0.95 \mu \mathrm{m}$ than at other size ranges, except for summer. In contrast, a previous study reported a coarse mode at 3.2-5.6 $\mu \mathrm{m}$, in addition to a droplet mode for a coastal site in Guangzhou, due to substantial influence of sea-salt (Liu et al., 2008). The absence of coarse mode for $\mathrm{SO}_{4}{ }^{2-}$ was likely due to the limited influence of sea-salt or dust on the formation of $\mathrm{SO}_{4}{ }^{2-}$ at this site. However, correlations of $\mathrm{SO}_{4}{ }^{2-}$ with $\mathrm{Ca}^{2+}$ and $\mathrm{Mg}^{2+}$ in coarse particles (Table S2) still indicated the influence of sea-salt and dust on the formation of $\mathrm{SO}_{4}{ }^{2-}$ (Yeatman et al., 2001). Through PMF analysis (Figs. S3 and S4), $\sim 40 \%$ and $\sim 35 \%$ of the modelled sulfate $(>60 \%)$ in coarse particles can be explained by the influence of dust and sea-salt, respectively.

Different from $\mathrm{SO}_{4}{ }^{2-}$, the distribution of $\mathrm{NO}_{3}{ }^{-}$clearly varied over the four seasons (Fig. 2). It was unimodally distributed in summer and autumn, peaking at coarse mode $(3.0-7.2 \mu \mathrm{m})$. The coarse-mode $\mathrm{NO}_{3}^{-}$was mainly related to soil/dust, with high correlations of $\mathrm{NO}_{3}^{-}$with $\mathrm{Ca}^{2+}(\mathrm{R}=$ $0.89, p<0.01)$ and $\mathrm{Mg}^{2+}(\mathrm{R}=0.88, p<0.01)$. PMF analysis further showed that $\sim 60 \%$ of the modelled nitrate in coarse particles were most likely associated with dust (Fig. S4). In addition, $\mathrm{NO}_{3}{ }^{-}$also appeared with potassium $(\mathrm{R}=0.76, p<0.01)$ and ammonium $(\mathrm{R}=0.80, p<0.01)$ in coarse particles. In winter and spring, $\mathrm{NO}_{3}^{-}$was observed to be bimodally distributed, with an additional peak at $0.49-0.95 \mu \mathrm{m}$. Correspondingly, the mean values $(0.03$, 0.04 ) of NOR at $0.49-0.95 \mu \mathrm{m}$ were relatively higher in these seasons. These distributions were consistent with those 
(a)
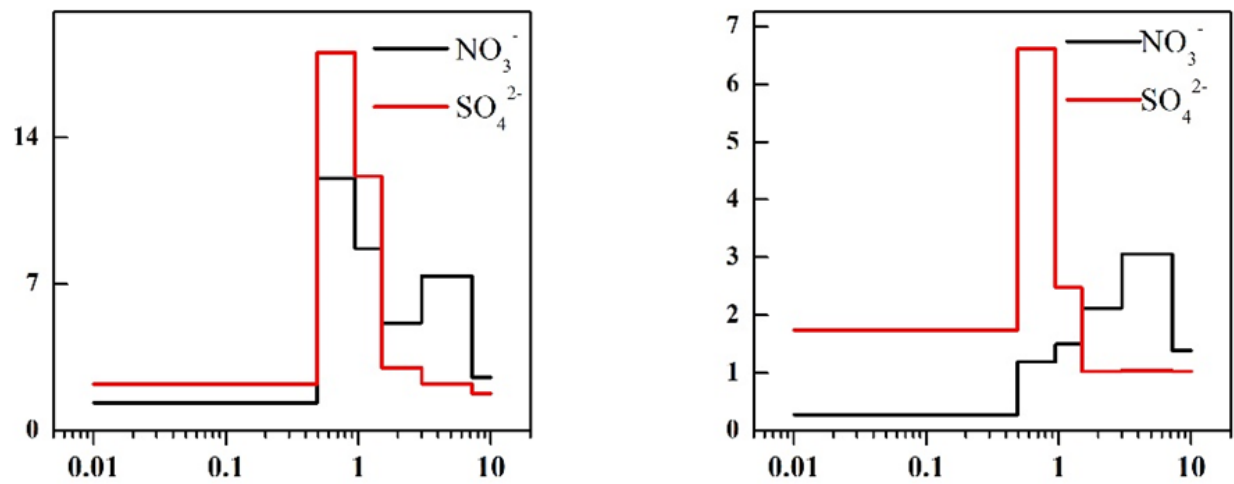

(b)

(c)

(d)
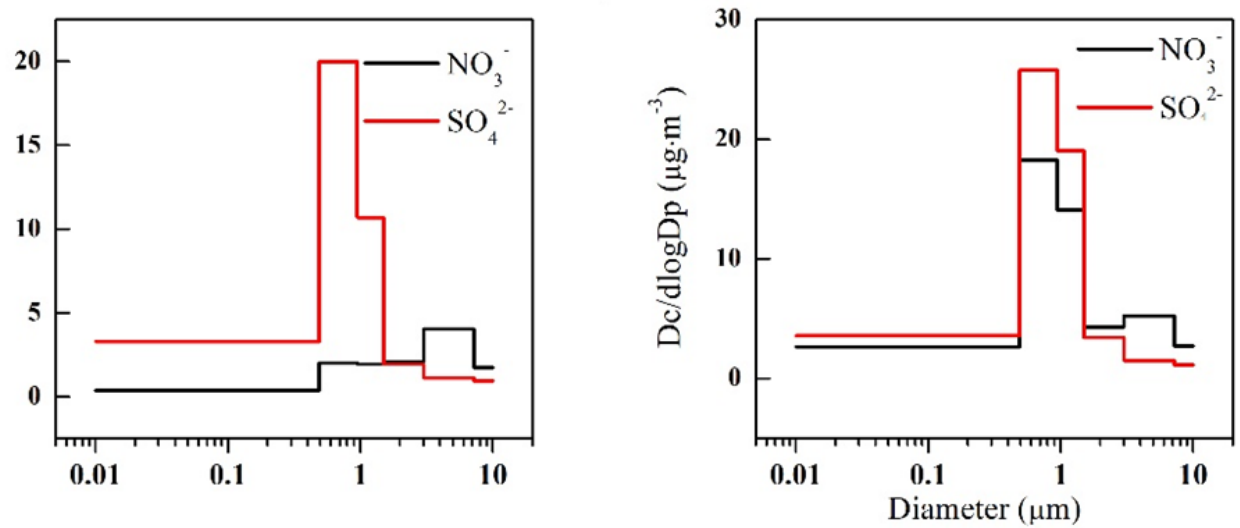

Fig. 2. Size distribution of $\mathrm{NO}_{3}{ }^{-}$and $\mathrm{SO}_{4}{ }^{2-}$ over the four seasons: (a) spring, (b) summer, (c) autumn, (d) winter.

observed in previous studies in Guangzhou (Liu et al., 2008). A relatively higher temperature $\left(25.6-30.7^{\circ} \mathrm{C}\right)$ resulted in the dissociation of particulate $\mathrm{NH}_{4} \mathrm{NO}_{3}$, which might explain the absence of $\mathrm{NO}_{3}^{-}$peak at $0.49-0.95 \mu \mathrm{m}$ in summer and autumn (Tai et al., 2010). Likewise, the correlations of $\mathrm{NO}_{3}{ }^{-}$and $\mathrm{NH}_{4}^{+}$at $<0.49 \mu \mathrm{m}, 0.49-0.95 \mu \mathrm{m}$ and $0.95-1.5 \mu \mathrm{m}$ were relatively higher in spring and winter $(\mathrm{R}=0.75,0.84$ and $0.83 ; p<0.01)$, compared to those in summer and autumn $(\mathrm{R}=0.16,0.53$ and 0.36 ; $p<$ 0.01 ), as shown in Table S2. Similarly, Yue et al. (2015) found that the linear correlation between $\mathrm{NO}_{3}{ }^{-}$and $\mathrm{NH}_{4}{ }^{+}$in $\mathrm{PM}_{2.5}$ was higher in winter and spring than in summer and autumn in Guangzhou. It indicated that the $\mathrm{NO}_{3}{ }^{-}$formed at these size ranges most probably co-existed with ammonium in spring and winter (Pathak et al., 2009).

\section{Factors Influencing the Formation of Sulfate and Nitrate} $\mathrm{O}_{3}$

The relationships of SOR and NOR versus $\mathrm{O}_{3}$ are illustrated in Fig. 3. It can be seen that SOR was moderately correlated $(\mathrm{R}=0.44, p<0.01)$ with $\mathrm{O}_{3}$ at $<0.49 \mu \mathrm{m}$. The median values of SOR at $<0.49 \mu \mathrm{m}$ increased from 0.09 to 0.20 with increasing $\mathrm{O}_{3}$ (Fig. 3(a)). This result indicates that $\mathrm{SO}_{4}{ }^{2-}$ in $<0.49 \mu \mathrm{m}$ particles was contributed by gasphase photochemical oxidation of $\mathrm{SO}_{2}$. Similarly, Liu et al. (2008) reported that sulfate in the size range of 0.32 $0.56 \mu \mathrm{m}$ was formed by gas-particle conversion in the
PRD region, China. The median of SOR in $0.49-3.0 \mu \mathrm{m}$ particles had no obvious increase with increasing $\mathrm{O}_{3}$. Therefore, $\mathrm{SO}_{4}{ }^{2-}$ in this size range may be formed through the aqueous oxidation of $\mathrm{SO}_{2}$, which was less dependent on the level of $\mathrm{O}_{3}$. In previous work, $\mathrm{SO}_{4}{ }^{2-}$ in the range of $0.56-1.0 \mu \mathrm{m}$ was mainly attributed to in-cloud processing (Liu et al., 2008).

NOR at $<0.49 \mu \mathrm{m}$ was correlated with $\mathrm{O}_{3}(\mathrm{R}=0.45, p<$ $0.01)$ in winter. NOR at $0.49-0.95 \mu \mathrm{m}$ and $0.95-1.5 \mu \mathrm{m}$ was weakly correlated with $\mathrm{O}_{3}$ and $\mathrm{RH}$ in winter. In addition, $\mathrm{PM}_{0.49}$ in 35 out of 37 samples was in an ammonium-rich $\left(\left[\mathrm{NH}_{4}{ }^{+}\right] /\left[\mathrm{SO}_{4}{ }^{2-}\right]>1.5\right)$ condition (Fig. 4). $\mathrm{NO}_{3}{ }^{-}$was highly correlated $(\mathrm{R}=0.64, p<0.01)$ with ammonium in this size range. Therefore, the formation of $\mathrm{NO}_{3}{ }^{-}$was most likely via homogeneous gas-phase reactions, in the form of $\mathrm{NH}_{4} \mathrm{NO}_{3}$. Similarly, Pathak et al. (2009) and Huang et al. (2011) found that $\mathrm{NH}_{4} \mathrm{NO}_{3}$ in $\mathrm{PM}_{2.5}$ partly resulted from homogeneous gas-phase reactions in Guangzhou, China.

As shown in Figs. 3(b)-3(c), NOR at 1.5-3.0 $\mu \mathrm{m}$ had limited correlations with $\mathrm{O}_{3}(\mathrm{R}=0.26, p<0.01)$, temperature $(\mathrm{R}=0.22, p<0.05)$ and $\mathrm{RH}(\mathrm{R}=0.20, p<0.05)$. It indicates that the formation of $\mathrm{NO}_{3}^{-}$at this size range had limited dependence on temperature, $\mathrm{O}_{3}$ and $\mathrm{RH}$. Instead, high correlations of $\mathrm{NO}_{3}^{-}$with $\mathrm{Ca}^{2+}(\mathrm{R}=0.64, p<0.01)$ and $\mathrm{Mg}^{2+}$ $(\mathrm{R}=0.80, p<0.01)$ were observed. This result might suggest that $\mathrm{NO}_{3}^{-}$was in the forms of $\mathrm{Ca}\left(\mathrm{NO}_{3}\right)_{2}$ and $\mathrm{Mg}\left(\mathrm{NO}_{3}\right)_{2}$ in this size range, most likely via heterogeneous reactions 


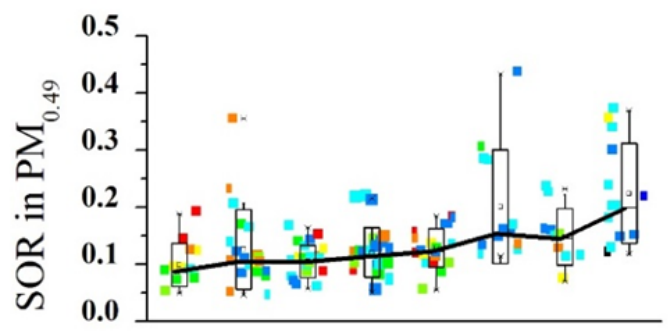

(a)

(b)


(c)

Fig. 3. (a) SOR at $<0.49 \mu \mathrm{m}$ and NOR at 1.5-3.0 $\mu \mathrm{m}$ versus (b) the concentration of $\mathrm{O}_{3}$ and (c) RH, respectively. The color scale in the legend represents temperature $\left({ }^{\circ} \mathrm{C}\right)$.

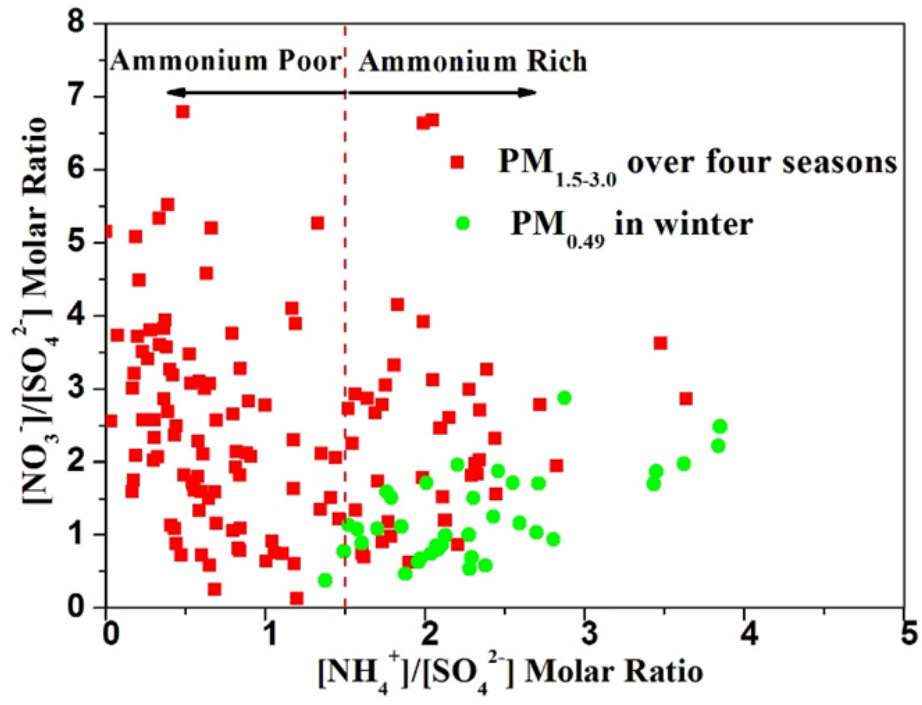

Fig. 4. The relationship between the ratios of $\left[\mathrm{NH}_{4}^{+}\right] /\left[\mathrm{SO}_{4}{ }^{2-}\right]$ and $\left[\mathrm{NO}_{3}{ }^{-}\right] /\left[\mathrm{SO}_{4}{ }^{2-}\right]$ for $\mathrm{PM}_{1.5-3}$ over the four seasons and $\mathrm{PM}_{0.49}$ for winter, respectively. 
between $\mathrm{NO}_{2} / \mathrm{HNO}_{3}$ and these alkaline compositions (Pathak et al., 2009; Tao et al., 2016). Correspondingly, $\mathrm{PM}_{1.5-3.0}$ in 89 out of 130 samples was assigned as ammonium-poor (Fig. 4), indicating the limited formation of $\mathrm{NO}_{3}^{-}$as $\mathrm{NH}_{4} \mathrm{NO}_{3}$ (Pathak et al., 2009).

\section{RH}

Guangzhou is influenced by the subtropical monsoon climate, with rainy seasons from April to September while the remaining months belong to dry season. Therefore, spring, summer and autumn are regarded as rainy seasons.

During rainy seasons, SOR was negatively correlated with RH (Fig. 5(a)) in the range of $<0.49 \mu \mathrm{m}(\mathrm{R}=-0.66$, $p<0.01), 0.49-0.95 \mu \mathrm{m}(\mathrm{R}=-0.43, p<0.01)$ and $0.95-$ $1.5 \mu \mathrm{m}(\mathrm{R}=-0.3, p<0.01)$. This was not in agreement with the corresponding values reported in previous studies (Tan et al., 2009a; Qin et al., 2015). In the present study, relatively higher humidity air masses originated from southeast air masses (Fig. S2) and more precipitation during the rainy seasons (Table $\mathrm{S} 1$ ) could remove the particulate matter (Tao et al., 2016). In contrast, the median of SOR at 0.49-3.0 $\mu \mathrm{m}$ increased with increasing RH (Fig. 5(b)) in dry seasons (winter). SOR was positively correlated with $\mathrm{RH}$ in the range of $0.49-0.95 \mu \mathrm{m}(\mathrm{R}=0.65, p<0.01)$, $0.95-1.5 \mu \mathrm{m}(\mathrm{R}=0.62, p<0.01)$ and $1.5-3.0 \mu \mathrm{m}(\mathrm{R}=$ $0.57, p<0.01)$. This result suggests that the aqueous oxidation of $\mathrm{SO}_{2}$ was an important pathway. Similarly, higher concentrations of droplet-mode sulfate were associated with higher RH in Hong Kong (Zhuang et al., 1999).
Huang et al. (2016) found that RH had a highly positive correlation with SOR in the range of $0.43-0.65 \mu \mathrm{m}(\mathrm{R}=$ $0.68, p<0.01), 0.65-1.1 \mu \mathrm{m}(\mathrm{R}=0.75, p<0.01)$ and $1.1-$ $2.1 \mu \mathrm{m}(\mathrm{R}=0.77, p<0.01)$ during 2013-2014 in Beijing.

\section{$\mathrm{H}^{+}$air, $\mathrm{pH}$ and $\mathrm{NO}_{2}$}

Aerosol $\mathrm{pH}$ and $\mathrm{H}^{+}$air was calculated by the ISORROPIA II model, which is a thermodynamic equilibrium model for $\mathrm{NH}_{4}{ }^{+}-\mathrm{K}^{+}-\mathrm{Ca}^{2+}-\mathrm{Na}^{+}-\mathrm{Mg}^{2+}-\mathrm{SO}_{4}{ }^{2-}-\mathrm{NO}_{3}{ }^{-}-\mathrm{H}_{2} \mathrm{O}$ (Fountoukis and Nenes, 2007). $\mathrm{H}_{\text {air }}^{+}\left(\mathrm{nmol} \mathrm{m}^{-3}\right)$ refers to the hydronium ion concentration per volume air. The $\mathrm{H}^{+}$air, $\mathrm{pH}$, and their correlation coefficients with SOR and NOR in the sizesegregated fraction are listed in Table 3. Average $\mathrm{H}^{+}$air and $\mathrm{pH}$ ranged from 0.6 to 10.2 and 2.6 to 5.6, respectively. The calculated $\mathrm{pH}$ was not in agreement with previous studies which reported an average aerosol $\mathrm{pH}<1$ in Guangzhou, calculated by AIM-II model (Pathak et al., 2009; Fu et al., 2015). This might be attributed to the underestimation of aerosol pH with AIM-II (Yao et al., 2006).

It is expected that the highest acidity (highest $\mathrm{H}^{+}$air $/$lowest $\mathrm{pH}$ ) was obtained in the size range of $0.49-0.95 \mu \mathrm{m}$, which was most likely due to the favorable formation of $\mathrm{SO}_{4}{ }^{2-}$ in this size range, as previously discussed. $\mathrm{H}^{+}$air and $\mathrm{pH}$ had no clear correlation with NOR and SOR at $<0.49 \mu \mathrm{m}$. This is consistent with previous discussions that the formation of $\mathrm{SO}_{4}{ }^{2-}$ and $\mathrm{NO}_{3}{ }^{-}$at this size range was via homogeneous gas-phase reactions followed by condensation. This pathway is not likely to be influenced by aerosol acidity. On the contrary, there was a high abundance of ammonium
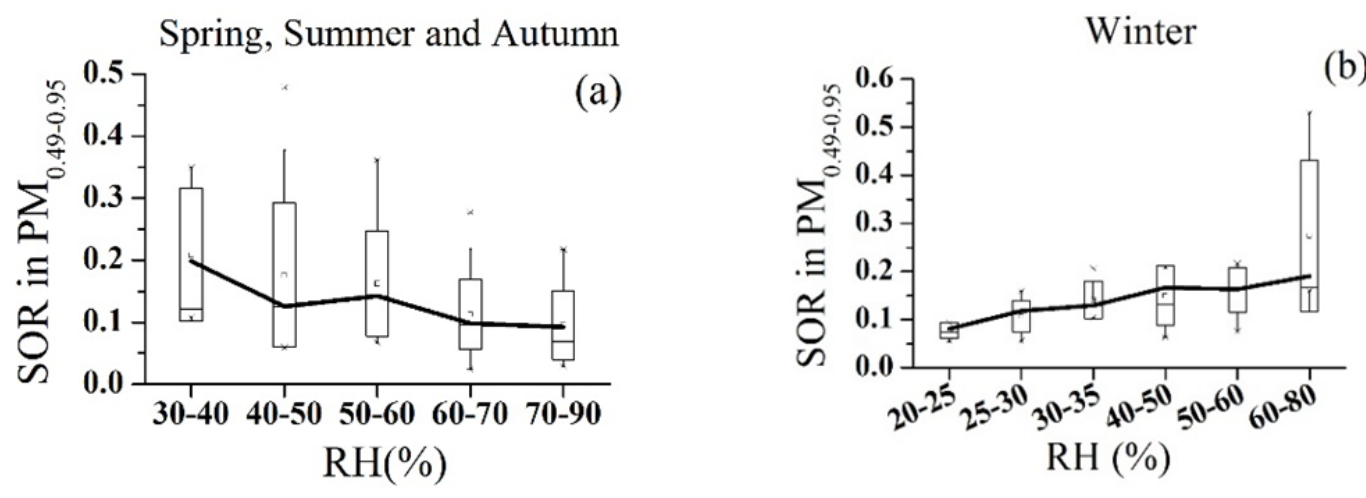

Fig. 5. SOR at $0.49-0.95 \mu \mathrm{m}$ versus RH over the four seasons.

Table 3. $\mathrm{H}^{+}$air and $\mathrm{pH}($ mean $\pm \mathrm{SD})$, and correlation coefficients of SOR and NOR with $\mathrm{H}^{+}$air and $\mathrm{pH}$ in size-segregated aerosols.

\begin{tabular}{|c|c|c|c|c|c|}
\hline \multirow{2}{*}{ Size-segregated aerosol } & \multirow{2}{*}{$\mathrm{H}^{+}$air $\left(\mathrm{nmol} \mathrm{m}^{-3}\right)$} & \multirow{2}{*}{$\mathrm{pH}$} & \multicolumn{3}{|c|}{ Correlation coefficients } \\
\hline & & & & $\mathrm{H}_{\text {air }}^{+}$ & $\mathrm{pH}$ \\
\hline \multirow[t]{2}{*}{$<0.49 \mu \mathrm{m}$} & $3.0 \pm 11.0$ & $5.6 \pm 3.0$ & SOR & 0.09 & 0.08 \\
\hline & & & NOR & 0.08 & -0.04 \\
\hline \multirow[t]{2}{*}{$0.49-0.95 \mu \mathrm{m}$} & $10.2 \pm 27.7$ & $2.6 \pm 3.4$ & SOR & 0.11 & $-0.21^{*}$ \\
\hline & & & NOR & $0.53 * *$ & $-0.29 *$ \\
\hline \multirow[t]{2}{*}{$0.95-1.5 \mu \mathrm{m}$} & $3.7 \pm 14.8$ & $4.8 \pm 3.4$ & SOR & 0.12 & $-0.29 * *$ \\
\hline & & & NOR & $0.57 * *$ & $-0.58 * *$ \\
\hline \multirow[t]{2}{*}{$1.5-3.0 \mu \mathrm{m}$} & $0.6 \pm 2.5$ & $5.6 \pm 3.0$ & SOR & -0.05 & 0.13 \\
\hline & & & NOR & 0.20 & -0.13 \\
\hline
\end{tabular}

** $p<0.01 . * p<0.05$. 
to neutralize the condensed acids. However, in ammoniumpoor samples at $0.49-1.5 \mu \mathrm{m}$, the formation of $\mathrm{SO}_{4}{ }^{2-}$ and $\mathrm{NO}_{3}{ }^{-}$could acidify aerosols $(\mathrm{R}=-0.29,-0.29,-0.58 ; p<$ 0.01 ; and $\mathrm{R}=-0.21, p<0.05)$.

Wang et al. (2016) and Cheng et al. (2016) found that aqueous oxidation of $\mathrm{SO}_{2}$ by $\mathrm{NO}_{2}$ was essential for the efficient formation of sulfate in fine aerosols under high $\mathrm{RH}$ or cloud conditions with $\mathrm{NH}_{3}$ neutralization. However, our data show that SOR at $<0.49 \mu \mathrm{m}, 0.49-0.95 \mu \mathrm{m}$, $0.95-1.5 \mu \mathrm{m}$ and $1.5-3.0 \mu \mathrm{m}$ had no significant variation with increasing $\mathrm{NO}_{2}$ (Fig. S6), due to the acidic nature of these particles $(\mathrm{pH}=2.6-5.6)$. This result also indicates that this pathway is probably unimportant in the atmosphere of Guangzhou (Guo et al., 2017; Liu et al., 2017b).

\section{CONCLUSION}

The formation mechanisms of size-resolved samples of $\mathrm{SO}_{4}{ }^{2-}$ and $\mathrm{NO}_{3}{ }^{-}$from the atmosphere of Guangzhou across the four seasons were investigated. The main factors influencing the formation of $\mathrm{SO}_{4}{ }^{2-}$ and $\mathrm{NO}_{3}{ }^{-}$, including the $\mathrm{O}_{3}$, $\mathrm{RH}$, aerosol acidity and gaseous pollutants, were evaluated. It was found that $\mathrm{SO}_{4}{ }^{2-}$ and $\mathrm{NO}_{3}{ }^{-}$accounted for more than $60 \%$ of the total water-soluble inorganic compounds in $\mathrm{PM}_{3}$. An abundance of clean air and rainfall during the rainy seasons resulted in a negative correlation between the SOR and the RH. However, due to the important role of the aqueous oxidation of $\mathrm{SO}_{2}$ in forming $\mathrm{SO}_{4}{ }^{2-}$, the SOR showed a positive correlation with the $\mathrm{RH}$ during the dry season (winter). The size-resolved analysis shows that the $\mathrm{SO}_{4}{ }^{2-}$ in $<0.49 \mu \mathrm{m}$ particles was mainly formed through the oxidation of $\mathrm{SO}_{2}$ by gas-phase photochemical reactions, whereas the $\mathrm{SO}_{4}{ }^{2-}$ in larger particles $(0.49-3.0 \mu \mathrm{m})$ was highly influenced by the RH. The formation of $\mathrm{NO}_{3}^{-}$as $\mathrm{Ca}\left(\mathrm{NO}_{3}\right)_{2}$ and $\mathrm{Mg}\left(\mathrm{NO}_{3}\right)_{2}$ in $1.5-$ $3.0 \mu \mathrm{m}$ particles was primarily attributable to heterogeneous reactions during all four seasons. Winter facilitated the formation of $\mathrm{NO}_{3}{ }^{-}$in particles $<0.49 \mu \mathrm{m}$ as ammonium nitrate via homogeneous gas-phase reactions. The inclusion of size-resolved and seasonal characteristics improves our understanding of the formation of sulfate and nitrate and enables us to distinguish the controlling mechanisms or factors.

\section{ACKNOWLEDGMENTS}

This work was supported by the National Nature Science Foundation of China (No. 41775124 and 41877307), the Science and Technology Project of Guangzhou, China (No. 201803030032), the State Key Laboratory of Organic Geochemistry (SKLOGA2016-A05), and "Technology innovation project" from Guangzhou Institute of Geochemistry, Chinese Academy of Sciences. We also acknowledge the NOAA Air Resources Laboratory (ARL) for the provision of the HYSPLIT transport and dispersion model and READY website (http://ready.arl.noaa.gov) used in this publication. This is contribution No. IS-2660 from GIGCAS.

\section{SUPPLEMENTARY MATERIAL}

Supplementary data associated with this article can be found in the online version at http://www.aaqr.org.

\section{REFERENCES}

Blitz, M.A., Hughes, K.J. and Pilling, M.J. (2003). Determination of the high-pressure limiting rate coefficient and the enthalpy of reaction for $\mathrm{OH}+\mathrm{SO}_{2} . J$. Phys. Chem. A 107: 1971-1978.

Cao, J.J., Shen, Z.X., Chow, J.C., Watson, J.G., Lee, S.C., Tie, X.X., Ho, K.F., Wang, G.H. and Han, Y.M. (2012). Winter and summer $\mathrm{PM}_{2.5}$ chemical compositions in fourteen Chinese cities. J. Air Waste Manage. Assoc. 62: 1214-1226.

Chang, S.Y., Chou, C.C.K., Liu, S. and Zhang, Y. (2013). The characteristics of $\mathrm{PM}_{2.5}$ and its chemical compositions between different prevailing wind patterns in Guangzhou. Aerosol Air Qual. Res. 13: 1373-1383.

Cheng, Y., Zheng, G., Wei, C., Mu, Q., Zheng, B., Wang, Z., Gao, M., Zhang, Q., He, K., Carmichael, G., Poschl, U. and $\mathrm{Su}, \mathrm{H}$. (2016). Reactive nitrogen chemistry in aerosol water as a source of sulfate during haze events in China. Sci. Adv. 2: e1601530.

Fountoukis, C. and Nenes, A. (2007). ISORROPIA II: A computationally efficient thermodynamic equilibrium model for $\mathrm{K}^{+}-\mathrm{Ca}^{2+}-\mathrm{Mg}^{2+}-\mathrm{NH}_{4}{ }^{+}-\mathrm{Na}^{+}-\mathrm{SO}_{4}{ }^{2-}-\mathrm{NO}_{3}{ }^{-}-\mathrm{Cl}^{-}-\mathrm{H}_{2} \mathrm{O}$ aerosols. Atmos. Chem. Phys. 7: 4639-4659.

Fu, X., Guo, H., Wang, X., Ding, X., He, Q., Liu, T. and Zhang, Z. (2015). $\mathrm{PM}_{2.5}$ acidity at a background site in the Pearl River Delta region in fall-winter of 2007-2012. J. Hazard. Mater. 286: 484-492.

Ge, X., He, Y., Sun, Y., Xu, J., Wang, J., Shen, Y. and Chen, M. (2017). Characteristics and formation mechanisms of fine particulate nitrate in typical urban areas in China. Atmosphere 8:62.

Guo, H., Weber, R.J. and Nenes, A. (2017). High levels of ammonia do not raise fine particle $\mathrm{pH}$ sufficiently to yield nitrogen oxide-dominated sulfate production. Sci. Rep. 7: 12109.

Han, T., Liu, X., Zhang, Y., Gu, J., Tian, H., Zeng, L., Chang, S.Y., Cheng, Y., Lu, K. and Hu, M. (2014). Chemical characteristics of $\mathrm{PM}_{10}$ during the summer in the mega-city Guangzhou, China. Atmos. Res. 137: 2534.

Herrmann, H., Schaefer, T., Tilgner, A., Styler, S.A., Weller, C., Teich, M. and Otto, T. (2015). Tropospheric aqueous-phase chemistry: Kinetics, mechanisms, and its coupling to a changing gas phase. Chem. Rev. 115: 4259-4334.

Huang, R.J., Zhang, Y., Bozzetti, C., Ho, K.F., Cao, J.J., Han, Y., Daellenbach, K.R., Slowik, J.G., Platt, S.M., Canonaco, F., Zotter, P., Wolf, R., Pieber, S.M., Bruns, E.A., Crippa, M., Ciarelli, G., Piazzalunga, A., Schwikowski, M., Abbaszade, G., Schnelle-Kreis, J., Zimmermann, R., An, Z., Szidat, S., Baltensperger, U., El Haddad, I. and Prevot, A.S.H. (2014). High secondary aerosol contribution to particulate pollution during haze 
events in China. Nature 514: 218-222.

Huang, X., Qiu, R., Chan, C.K. and Kant, P.R. (2011). Evidence of high $\mathrm{PM}_{2.5}$ strong acidity in ammonia-rich atmosphere of Guangzhou, China: Transition in pathways of ambient ammonia to form aerosol ammonium at $\mathrm{NH}_{4}{ }^{+} / \mathrm{SO}_{4}{ }^{2-}=1.5$. Atmos. Res. 99: 488-495.

Huang, X., Liu, Z., Zhang, J., Wen, T., Ji, D. and Wang, Y. (2016). Seasonal variation and secondary formation of size-segregated aerosol water-soluble inorganic ions during pollution episodes in Beijing. Atmos. Res. 168: 70-79.

Lai, S.C., Zou, S.C., Cao, J.J., Lee, S.C. and Ho, K.F. (2007). Characterizing ionic species in $\mathrm{PM}_{2.5}$ and $\mathrm{PM}_{10}$ in four Pearl River Delta cities, South China. J. Environ. Sci. 19: 939-947.

Li, W., Liu, X., Zhang, Y., Sun, K., Wu, Y., Xue, R., Zeng, L., Qu, Y. and An, J. (2018). Characteristics and formation mechanism of regional haze episodes in the Pearl River Delta of China. J. Environ. Sci. 63: 236249.

Li, X., Wang, L., Ji, D., Wen, T., Pan, Y., Sun, Y. and Wang, Y. (2013). Characterization of the size-segregated water-soluble inorganic ions in the Jing-Jin-Ji urban agglomeration: Spatial/temporal variability, size distribution and sources. Atmos. Environ. 77: 250-259.

Liu, J., Wu, D., Fan, S., Mao, X. and Chen, H. (2017a). A one-year, on-line, multi-site observational study on water-soluble inorganic ions in $\mathrm{PM}_{2.5}$ over the Pearl River Delta region, China. Sci. Total Environ. 601: 1720-1732.

Liu, M., Song, Y., Zhou, T., Xu, Z., Yan, C., Zheng, M., $\mathrm{Wu}, \mathrm{Z}$., Hu, M., Wu, Y. and Zhu, T. (2017b). Fine particle $\mathrm{pH}$ during severe haze episodes in northern China. Geophys. Res. Lett. 44: 5213-5221.

Liu, S., Hu, M., Slanina, S., He, L.Y., Niu, Y.W., Bruegemann, E., Gnauk, T. and Herrmann, H. (2008). Size distribution and source analysis of ionic compositions of aerosols in polluted periods at Xinken in Pearl River Delta (PRD) of China. Atmos. Environ. 42: 6284-6295.

Liu, X., Sun, K., Qu, Y., Hu, M., Sun, Y., Zhang, F. and Zhang, Y. (2015). Secondary formation of sulfate and nitrate during a haze episode in megacity Beijing, China. Aerosol Air Qual. Res. 15: 2246-2257.

Meng, Z.Y. and Seinfeld, J.H. (1994). On the source of the submicrometer droplet mode of urban and regional aerosols. Aerosol Sci. Technol. 20: 253-265.

Nguyen, T.K.V., Zhang, Q., Jimenez, J.L., Pike, M. and Carlton, A.G. (2016). Liquid water: Ubiquitous contributor to aerosol mass. Environ. Sci. Technol. Lett. 3: 257-263.

Pathak, R.K., Wu, W.S. and Wang, T. (2009). Summertime $\mathrm{PM}_{2.5}$ ionic species in four major cities of China: Nitrate formation in an ammonia-deficient atmosphere. Atmos. Chem. Phys. 9: 1711-1722.

Poschl, U. (2005). Atmospheric aerosols: Composition, transformation, climate and health effects. Angew. Chem. Int. Ed. 44: 7520-7540.

Pun, B.K. and Seigneur, C. (2001). Sensitivity of particulate matter nitrate formation to precursor emissions in the California San Joaquin Valley. Environ. Sci. Technol. 35:
2979-2987.

Qin, M., Wang, X., Hu, Y., Huang, X., He, L., Zhong, L., Song, Y., Hu, M. and Zhang, Y. (2015). Formation of particulate sulfate and nitrate over the Pearl River Delta in the fall: Diagnostic analysis using the Community Multiscale Air Quality model. Atmos. Environ. 112: 8189.

Seinfeld, J.H. and Pandis, S.N. (2006). Atmospheric chemistry and physics: From air pollution to climate change. 2nd ed. Wiley, New York.

Stockwell, W.R. and Calvert, J.G. (1983). The mechanism of the $\mathrm{HO}-\mathrm{SO}_{2}$ reaction. Atmos. Environ. 17: 2231-2235.

Sun, Y.L., Wang, Z.F., Fu, P.Q., Yang, T., Jiang, Q., Dong, H.B., Li, J. and Jia, J.J. (2013). Aerosol composition, sources and processes during wintertime in Beijing, China. Atmos. Chem. Phys. 13: 4577-4592.

Tai, A.P.K., Mickley, L.J. and Jacob, D.J. (2010). Correlations between fine particulate matter $\left(\mathrm{PM}_{2.5}\right)$ and meteorological variables in the United States: Implications for the sensitivity of $\mathrm{PM}_{2.5}$ to climate change. Atmos. Environ. 44: 3976-3984.

Tan, J.H., Duan, J.C., Chen, D.H., Wang, X.H., Guo, S.J., Bi, X.H., Sheng, G.Y., He, K.B. and Fu, J.M. (2009a). Chemical characteristics of haze during summer and winter in Guangzhou. Atmos. Res. 94: 238-245.

Tan, J.H., Duan, J.C., He, K.B., Ma, Y.L., Duan, F.K., Chen, Y. and Fu, J.M. (2009b). Chemical characteristics of $\mathrm{PM}_{2.5}$ during a typical haze episode in Guangzhou. $J$. Environ. Sci. 21: 774-781.

Tao, J., Shen, Z.X., Zhu, C.S., Yue, J.H., Cao, J.J., Liu, S.X., Zhu, L.H. and Zhang, R.J. (2012). Seasonal variations and chemical characteristics of sub-micrometer particles $\left(\mathrm{PM}_{1}\right)$ in Guangzhou, China. Atmos. Res. 118: 222-231.

Tao, Y., Ye, X.N., Ma, Z., Xie, Y.Y., Wang, R.Y., Chen, J.M., Yang, X. and Jiang, S.Q. (2016). Insights into different nitrate formation mechanisms from seasonal variations of secondary inorganic aerosols in Shanghai. Atmos. Environ. 145: 1-9.

Wang, G.H., Zhang, R.Y., Gomez, M.E., Yang, L.X., Zamora, M.L., Hu, M., Lin, Y., Peng, J.F., Guo, S., Meng, J.J., Li, J.J., Cheng, C.L., Hu, T.F., Ren, Y.Q., Wang, Y.S., Gao, J., Cao, J.J., An, Z.S., Zhou, W.J., Li, G.H., Wang, J.Y., Tian, P.F., Marrero-Ortiz, W., Secrest, J., Du, Z.F., Zheng, J., Shang, D.J., Zeng, L.M., Shao, M., Wang, W.G., Huang, Y., Wang, Y., Zhu, Y J., Li, Y.X., Hu, J.X., Pan, B., Cai, L., Cheng, Y.T., Ji, Y.M., Zhang, F., Rosenfeld, D., Liss, P.S., Duce, R.A., Kolb, C.E. and Molina, M.J. (2016). Persistent sulfate formation from London Fog to Chinese haze. Proc. Natl. Acad. Sci. U.S.A. 113: 13630-13635.

Wang, J., Li, X., Zhang, W.K., Jiang, N., Zhang, R.Q. and Tang, X.Y. (2016b). Secondary $\mathrm{PM}_{2.5}$ in Zhengzhou, China: Chemical species based on three years of observations. Aerosol Air Qual. Res. 16: 91-104.

Wang, J., Zhang, J.S., Liu, Z.J., Wu, J.H., Zhang, Y.F., Han, S.Q., Zheng, X.J., Zhou, L.D., Feng, Y.C. and Zhu, T. (2017). Characterization of chemical compositions in size-segregated atmospheric particles during severe haze 
episodes in three mega-cities of China. Atmos. Res. 187: 138-146.

Wu, X., Deng, J., Chen, J., Hong, Y., Xu, L., Yin, L., Du, W., Hong, Z., Dai, N. and Yuan, C.S. (2017). Characteristics of water-soluble inorganic components and acidity of $\mathrm{PM}_{2.5}$ in a coastal city of China. Aerosol Air Qual. Res. 17: 2152-2164.

Yang, Y.R., Liu, X.G., Qu, Y., An, J.L., Jiang, R., Zhang, Y.H., Sun, Y.L., Wu, Z.J., Zhang, F., Xu, W.Q. and Ma, Q.X. (2015). Characteristics and formation mechanism of continuous hazes in China: A case study during the autumn of 2014 in the North China Plain. Atmos. Chem. Phys. 15: 8165-8178.

Yao, X.H., Chan, C.K., Fang, M., Cadle, S., Chan, T., Mulawa, P., He, K.B. and Ye, B.M. (2002). The watersoluble ionic composition of $\mathrm{PM}_{2.5}$ in Shanghai and Beijing, China. Atmos. Environ. 36: 4223-4234.

Yao, X.H., Ling, T.Y., Fang, M. and Chan, C.K. (2006). Comparison of thermodynamic predictions for in situ $\mathrm{pH}$ in $\mathrm{PM}_{2.5}$. Atmos. Environ. 40: 2835-2844.

Yeatman, S.G., Spokes, L.J. and Jickells, T.D. (2001). Comparisons of coarse-mode aerosol nitrate and ammonium at two polluted coastal sites. Atmos. Environ. 35: 1321-1335.

Yu, X., Yu, Q.Q., Zhu, M., Tang, M.J., Li, S., Yang, W.Q., Zhang, Y.L., Deng, W., Li, G.H., Yu, Y.G., Huang, Z.H., Song, W., Ding, X., Hu, Q.H., Li, J., Bi, X.H. and Wang, X.M. (2017). Water soluble organic nitrogen (WSON) in ambient fine particles over a megacity in south China:
Spatiotemporal variations and source apportionment. $J$. Geophys. Res. 122: 13045-13060.

Yue, D.L., Hu, M., Wu, Z.J., Guo, S., Wen, M.T., Nowak, A., Wehner, B., Wiedensohler, A., Takegawa, N., Kondo, Y., Wang, X.S., Li, Y.P., Zeng, L.M. and Zhang, Y.H. (2010). Variation of particle number size distributions and chemical compositions at the urban and downwind regional sites in the Pearl River Delta during summertime pollution episodes. Atmos. Chem. Phys. 10: 9431-9439.

Yue, D.L., Zhong, L.J., Zhang, T., Shen, J., Zhou, Y., Zeng, L.M., Dong, H.B. and Ye, S.Q. (2015). Pollution properties of water-soluble secondary inorganic ions in atmospheric $\mathrm{PM}_{2.5}$ in the Pearl River Delta Region. Aerosol Air Qual. Res. 15: 1737-1747.

Zheng, G.J., Duan, F.K., Su, H., Ma, Y.L., Cheng, Y., Zheng, B., Zhang, Q., Huang, T., Kimoto, T., Chang, D., Poschl, U., Cheng, Y.F. and He, K.B. (2015). Exploring the severe winter haze in Beijing: The impact of synoptic weather, regional transport and heterogeneous reactions. Atmos. Chem. Phys. 15: 2969-2983.

Zhuang, H., Chan, C.K., Fang, M. and Wexler, A.S. (1999). Size distributions of particulate sulfate, nitrate, and ammonium at a coastal site in Hong Kong. Atmos. Environ. 33: 843-853.

Received for review, August 15, 2018 Revised, January 29, 2019 Accepted, February 17, 2019 